\title{
The role of traditional beliefs in conservation of herpetofauna in Banten, Indonesia
}

\author{
Linda T. Uyeda, Entang Iskandar, Azhari Purbatrapsila, Joko Pamungkas \\ AARON WIRSING and RANDALl C. KyES
}

\begin{abstract}
Social taboos have been increasingly recognized for their role in determining human behaviour. Such informal institutions may also, in some instances, guide practices that serve as effective conservation measures. Here we present a case in Banten, Indonesia, where a local taboo has discouraged the collection of two herpetofaunal species, the water monitor lizard Varanus salvator and the reticulated python Python reticulatus, on Tinjil Island, an undeveloped island off the coast of Java. The taboo is not observed in the nearby mainland villages of Muara Dua and Cisiih, where the two species may be harvested for skin or meat, and where the water monitor may also be killed as a pest. Water monitors and reticulated pythons figure prominently in the international reptile leather trade, with skins produced from Indonesia's wild populations representing the highest percentage of total global exports of both lizard and snake skins. The site-specific taboo documented here provides a strong deterrent to collection of these species in a location where they could be subject to illicit harvest as populations in nearby mainland areas decrease. Preliminary evidence also suggests that belief in forest guardian spirits may extend protection to other wildlife species on Tinjil Island.
\end{abstract}

Keywords Indonesia, Python reticulatus, social taboos, traditional beliefs, Varanus salvator, wildlife conservation

\section{Introduction}

The importance of traditional beliefs and social norms in 1 the context of conservation has been recognized and documented (Colding \& Folke, 1997; Jones et al., 2008; Riley, 2010). Colding \& Folke (2001) refer to such social institutions as invisible systems of resource management in which informal, culture-based norms effectively guide human behaviour. As in Colding \& Folke (2001) we define

Linda T. Uyeda (Corresponding author) and AARON Wirsing School of Environmental and Forest Sciences, University of Washington, Box 352100 Seattle, WA, 98195-2100, USA. E-mail ltuyeda@gmail.com

Entang Iskandar, Azhari Purbatrapsila and Joko Pamungkas Primate Research Center, Bogor Agricultural University, Bogor, West Java, Indonesia

Randall C. Kyes Departments of Psychology and Global Health, Center for Global Field Study, and Washington National Primate Research Center, University of Washington, Seattle, USA

Received 19 April 2014. Revision requested 4 June 2014.

Accepted 21 July 2014. First published online 24 October 2014. taboos in a broad sense as a subset of these informal institutions, serving as prohibitions that are enforced by social custom rather than by government or official regulation. Taboos may serve to protect wildlife that otherwise might be exploited or persecuted, effectively aiding the conservation of potentially vulnerable populations. Identification of taboos and an understanding of local concerns can help to direct conservation efforts by facilitating the integration of local belief systems with formal management strategies.

In Indonesia, local cultures maintain traditional belief systems that may have an indirect influence on attitudes and behaviour towards animals (Wadley \& Colfer, 2004; Wessing, 2006). Although there may be regional commonalities in spiritual beliefs (Wessing, 2006), the country's c. 200 ethnic groups and $>500$ spoken languages (Ministry of Tourism and Creative Economy, Republic of Indonesia, 2013) also necessitate that social institutions be investigated at a finer scale to ensure greater understanding of local differences. Here we document a social taboo that serves to support official regulations in preventing collection of the water monitor lizard Varanus salvator and the reticulated python Python reticulatus on Tinjil Island, off the coast of Java. We also report interview data from the nearby mainland villages of Muara Dua and Cisiih on local knowledge and attitudes regarding these species. We aim to contribute specific knowledge on local perspectives and to discuss the role of traditional beliefs in conservation of wildlife populations in Indonesia.

\section{Study area}

Tinjil Island (c. 60o ha; Fig. 1) has served as a natural habitat breeding facility for long-tailed macaques Macaca fascicularis since 1987 (Kyes, 1993; Pamungkas et al., 1994) and is managed by the Primate Research Center of Bogor Agricultural University. Unauthorized access to the island is prohibited by official regulation of the Indonesian state-owned forestry company Perum Perhutani (UU PK No. 35 Tahun 1967 Juncto Pasal 5 ayat butir C dan Pasal 6 Peraturan Pemerintah No. 36 Tahun 1986). According to the official policy of Bogor Agricultural University, unauthorized removal of flora and fauna from the island is also prohibited. Tinjil Island remains undeveloped, with no permanent residents. Staff members are rotated on and off the island, with only 5-8 individuals residing in a small base camp at any given time. A select group of fishermen 


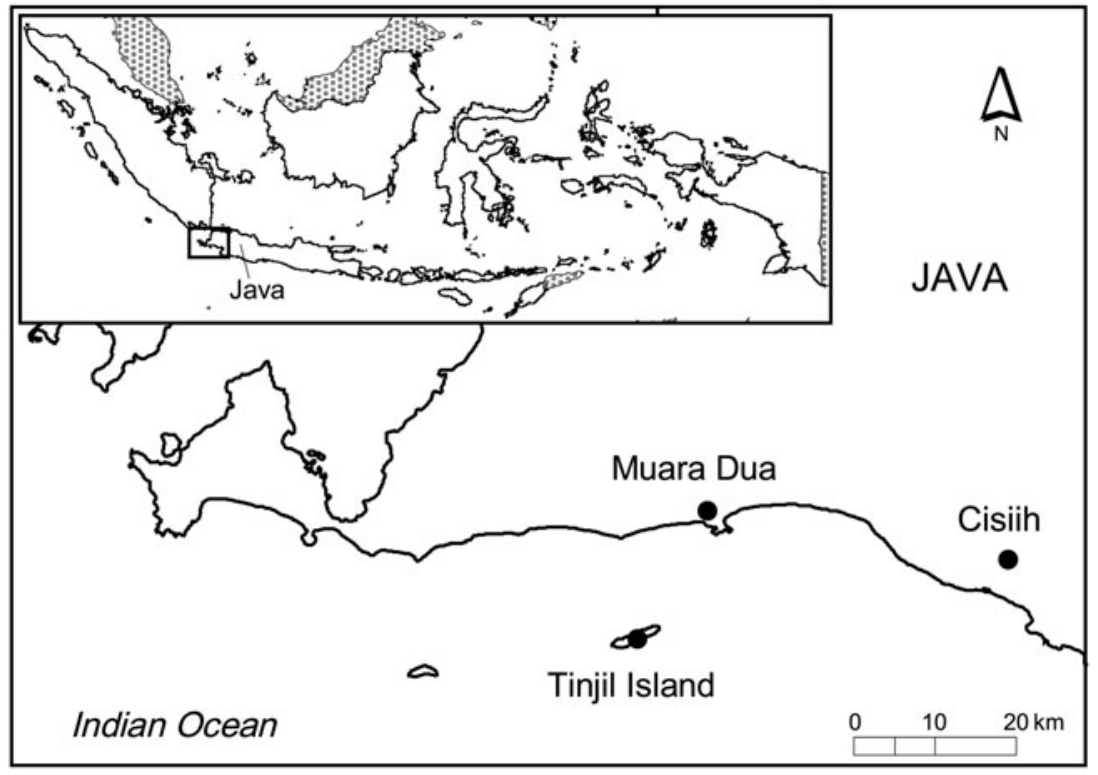

FIG. 1. Location of Tinjil Island and the villages of Muara Dua and Cisiih. The rectangle on the inset shows the location of the main map in Indonesia. (c. 8-12) have also been authorized to use three small camps on the island. Muara Dua, in Banten province on the island of Java, is c. $16 \mathrm{~km}$ from Tinjil Island and is the closest mainland village to the island. It is $45 \mathrm{~km}$ from the village of Cisiih, also in Banten province. The majority of staff and fishermen associated with Tinjil Island have established permanent residences in the area known as Muarabinuangeun, consisting of Muara Dua village and its neighbouring village of Binuangeun.

Water monitors and reticulated pythons are the only known large $(>2 \mathrm{~m}$ in length) reptile species on Tinjil Island. Water monitors are found throughout the island and are considered common in all three study locations, whereas reticulated pythons are encountered less frequently. These species are exploited consistently throughout Southeast Asia to supply the international reptile leather trade (Luxmoore \& Groombridge, 1990; Shine et al., 1998; Auliya, 2006). Indonesia is the primary exporter of skins of both species (Jenkins \& Broad, 1994; TRAFFIC and the IUCN/SSC Wildlife Trade Programme, 2004; Engler \& Parry-Jones, 2007; Kasterine et al., 2012), and both species are listed on Appendix II of CITES (CITES, 2014), with export quotas established annually (UNEP, 2013a,b).

\section{Methods}

We conducted individual and group (2-3 participants) interviews during 19 January-4 September 2013 as part of a broader interdisciplinary study investigating the behaviour and resource use of water monitors (Uyeda et al., 2012, 2013), and local attitudes and knowledge regarding this species. Interviewees were asked about their perceptions and knowledge of local herpetofauna, with an initial focus on water monitors. Interviews were semi-structured but casual, and questions were open-ended to encourage participants to express their perspectives and attitudes freely. Participants comprised adult residents of Muara Dua or Cisiih and individuals authorized to carry out activity on Tinjil Island. On Tinjil Island 15 individuals (13 men and two women) participated in 12 interviews; participants included individuals from each of the three fisherman camps as well as staff members from the base camp area. As most participants on Tinjil Island were permanent residents in the area of Muarabinuangeun, they were asked about both their permanent place of residence and Tinjil Island. We used a combination of convenience sampling (i.e. interviewing people who were easily accessible) and snowball sampling (i.e. identifying new participants based on the recommendation of current participants; Auerbach \& Silverstein, 2003) to identify participants in the villages of Muara Dua and Cisiih. In these villages 40 individuals (21 men and 19 women) participated in 23 interviews (12 in Muara Dua and 11 in Cisiih). The mean duration of interviews was 30 minutes, and interviews were conducted in Bahasa Indonesia.

\section{Results}

Social taboo on Tinjil Island

Throughout the course of the interviews a social taboo against the collection of water monitors and reticulated pythons on Tinjil Island emerged. We documented several versions of the taboo that were consistent in theme. In the first story a fisherman took a water monitor from Tinjil Island, killed it, and skinned it, intending to sell the skin. That night, the fisherman became possessed to the point of madness, running around wildly. An orang pintar (wise 
man) was sought for advice and he told the fisherman that the lizard wished to be returned to the island. The fisherman followed the advice of the orang pintar and brought the head of the lizard back to the exact location where the animal had been captured. Subsequently, the fisherman was healed.

Other versions of the taboo involved a fisherman encountering an exceptionally large reticulated python on Tinjil Island. The fisherman caught the snake with the intention of taking it to sell in the village. The snake's spirit entered the fisherman and spoke to him, requesting to be released. The fisherman became possessed and remained cursed until he returned the snake to the island.

We were unaware of these stories prior to beginning our research, and therefore initially we did not question Tinjil Island participants specifically about the existence of taboos. After learning of the taboo we began probing subsequent participants regarding their knowledge of any taboos related to wildlife. Each of the five male individuals on Tinjil Island questioned about taboos relayed a version of one or both of the taboo stories. Although neither of the women interviewed on Tinjil Island had knowledge of the taboo, both expressed a general belief in the presence of spirits on the island. All interviewees in Muara Dua and Cisiih were asked about their knowledge of wildlife taboos, with two former long-time staff members of Tinjil Island living in Muara Dua providing similar accounts of the taboo. None of the participants indicated knowledge of taboos prohibiting the harvest of any wildlife species in the villages of Muara Dua or Cisiih. Individuals with experience on Tinjil Island expressed that whereas they were afraid to harvest water monitors or reticulated pythons from the island, a person harming or even killing these species in the mainland villages would suffer no negative repercussions.

Individuals who were aware of the taboo had spent 3-24 years working on Tinjil Island, with younger workers having acquired knowledge of the taboo from their older coworkers. One less experienced fisherman reported what he had been told by others:

According to the elders the island is angker (haunted). If there is a snake, don't try to take it because it belongs to the orang sini (guardian spirit of the island). Other people said that snakes and monitor lizards belong to the orang sini. All of the elders know this, so I'm not brave enough to kill or to take one indiscriminately. People here fear being cursed.

Of the stories associated with the taboo, at least one was reported to have occurred in the recent past; several interviewees had heard of a fisherman becoming possessed when he had attempted to remove a snake from Tinjil Island c. 10 years previously. It was also noted that Tinjil Island had been haunted (angker) since long ago and that the neighbouring island, Pulau Deli, was also known to be haunted.

Interviewees who were familiar with the stories indicated that the taboo was a strong deterrent, discouraging attempts to take either of the species off the island despite the potential for financial gain. The following quotations illustrate such sentiments:

I'm scared to take a snake or a monitor lizard. I often get requests from Muarabinuangeun ...for skin, to make shoes, to make wallets, and the meat can also be eaten. It's not allowed, but if you put it into a bag, you could do it. Nobody would know. We're just scared because of what happened to the fisherman.

It's a warning for other fishermen. Now fishermen wouldn't dare to take even a single monitor lizard from here, even though there are requests for the meat. Honestly, the monitor lizards here are big, bigger than $10 \mathrm{~kg}$. They could be sold for 3,000-4,000 rupiah per kilo. But the fishermen are afraid now. They are afraid of what happened.

Interviewees specified that the taboo applied only to water monitors and reticulated pythons, although none could explain why other wildlife species were not included in the taboo. There was some evidence that belief in the taboo also conferred some degree of protection to other wildlife species. For example, although venomous snakes were generally viewed as a threat to human safety and had reportedly been killed on Tinjil Island, more than one individual expressed a reluctance to disturb any being on the island for any reason. A worker who had instinctively killed a venomous snake after it had bitten him had been extremely fearful of spiritual repercussions, although there were none. He explained:

Because of what happened with the fisherman and the snake, I'm afraid of it happening with all animals. If I see a snake, better to go around it. If I were to hit it, I'm afraid something bad would happen.

\section{Attitudes and local knowledge}

Several interviewees reported that independent collectors in the area of Muarabinuangeun continue to harvest water monitors and reticulated pythons for skin and to fulfil orders for water monitor meat. Although the meat is not eaten regularly as a protein source in the study area, local knowledge supported occasional consumption as a cure for skin ailments (Uyeda et al., 2014).

The majority of local people interviewed in Muara Dua and Cisiih reported keeping small livestock such as chickens, for personal consumption, and many participants reported having chased or killed a water monitor to protect chickens or ducks from predation. A number of people in both Muara Dua and Cisiih referred to water monitors as jahat, a word used to characterize unacceptable behaviour, with others calling the lizard a hama (pest). Although generally disliked, water monitors were not considered dangerous to humans.

There are no domestic livestock kept on Tinjil Island, and interviewees indicated that water monitors were left undisturbed, even when encountered at close proximity. In the island's camp areas the lizards were reportedly habituated to people, as supported by our previous observations (Uyeda, 2009; Uyeda et al., 2013). In contrast, inhabitants of Muara 
Dua and Cisiih reported that water monitors were likely to flee upon encountering humans.

Snakes were encountered only rarely in the villages, with the reticulated python and the Malayan pit viper Calloselasma rhodostoma being the most commonly encountered species. On Tinjil Island the Javanese pit viper Trimeresurus puniceus was the venomous snake observed most frequently, although it was not encountered often. Interviewees indicated that venomous species were generally killed on sight in the mainland villages because of the threat they posed to human safety. The nonvenomous reticulated python was rarely seen as a threat to humans, chickens or other livestock but was sometimes killed opportunistically for its skin or meat.

Participants reported a general decrease in populations of water monitors and reticulated pythons in Cisiih and Muarabinuangeun. Several participants noted that Tinjil Island was the only place where large water monitors were still seen, and they were reported to be larger and more numerous on the island than in Muara Dua, where it was speculated that observed population trends may be attributable to harvesting of the animals for skin and meat:

Pythons, I rarely see them; they're already gone around here. People have taken them.

In the past, there were many [monitor lizards], but now there aren't any big ones. They're hunted by people, the big ones.

Based on our personal observations as well as reports from interview participants, water monitors on Tinjil Island appear to have lower quality (scarred, peeling) skin than in Muara Dua or Cisiih and are thus considered less suitable for collection to supply the reptile leather trade.

\section{Discussion}

Interviews indicated that a local taboo guides behaviour in discouraging harvesting of water monitors and reticulated pythons on Tinjil Island. The location-specific nature of the taboo suggests it originated in beliefs associated with characteristics of the island. In traditional Javanese culture it is generally believed that spirits exist in most natural places and both inhabit and protect these areas (Wessing, 2006). Forests are perceived as forbidding places, home to fearsome forest guardians that may be angered by humans entering their territories or removing things without permission. The forest guardians are reputed to be powerful spirits that punish offenders by causing them to become disoriented or by subjecting them to illness or death (Wessing, 2006). The folklore documented here suggests that interview participants believed in the power of such forest guardians on Tinjil Island. As forest guardians are associated with isolated, wild forest rather than human-disturbed areas (Wessing, 2006), it is unsurprising that a taboo exists on Tinjil Island, which is secluded and largely untouched by humans. Similarly, we would expect to find less regard for a taboo involving forest guardians in the mainland villages, which are more developed.

The water monitor lizard is categorized as Least Concern on the IUCN Red List (Bennett et al., 2010), having demonstrated a certain degree of resilience to substantial harvesting pressure (Shine et al., 1998). However, Indonesia reported a total export volume of 6,201,615 wild-caught water monitor skins during 2000-2010 (Koch et al., 2013), and the impact of such collection on wild populations cannot be dismissed as insignificant. Although populations of reticulated pythons also seem able to withstand high volumes of harvest (Shine et al., 1999), the species has not been evaluated for the Red List, and anecdotal reports suggest that harvested populations have been depleted in some areas (Groombridge \& Luxmoore, 1991).

Despite official regulations protecting Tinjil Island's wildlife, and the poor quality of water monitor skins originating from the island, incentives for illicit harvest remain. The population status of monitor lizards and reticulated pythons in Muara Dua has not been evaluated formally but anecdotal reports from interview participants indicated that populations of both species have decreased there as a result of collection, whereas they remain more abundant on Tinjil Island. Interview responses also suggested that larger water monitors are more desirable to collectors than smaller individuals, and that their meat is still in demand. As populations of water monitors in Muarabinuangeun decrease, collectors may consider risking official sanctions to access larger specimens on Tinjil Island. Moreover, unlike in Cisiih and Muara Dua, water monitors on Tinjil Island are naïve to hunting and are less likely to avoid humans, and therefore they are vulnerable to collection. Reticulated python populations on the island could also be subject to collection pressure in the future as populations in nearby villages are depleted.

There is evidence to suggest that despite the speciesspecific nature of the taboo, belief in forest guardian spirits on Tinjil Island may influence behaviour towards all wildlife, and therefore any decline in such beliefs could also have negative consequences for other species. A variety of factors could contribute to the decline of local taboos, including an influx of people to the area who are unaware of or who do not believe in the taboo (Thalmann et al., 1993; Lingard et al., 2003), economic incentives resulting in deliberate disregard for the taboo (Jones et al., 2008), degradation of natural, wild lands, and a decline in belief if offenders do not appear to suffer any negative consequences.

In the case presented here, modern-day stories of fishermen becoming possessed after capturing water monitors and reticulated pythons on Tinjil Island have reinforced a taboo that appears to be based on a long-standing traditional belief in forest guardians. Individuals in the island's base and fisherman camps, and former Tinjil Island workers 
living in Muara Dua, were familiar with the folklore and expressed a strong belief in the taboo, which had been passed down to younger generations as they began their association with the island. However, the lack of knowledge about Tinjil Island among local people in mainland villages is a potential limitation to the conservation value of the taboo. Those who had no previous experience on the island appeared to be unaware of the taboo associated with the collection of herpetofauna there, and this ignorance could embolden individuals to harvest wildlife from Tinjil Island in the future. Increasing awareness of the taboo among people on the mainland may aid in pre-empting such efforts, and further investigation into the prevalence and scope of beliefs associated with forest guardians in this area could identify additional protection afforded to local wildlife species.

The value of sacred forests or groves to conservation has been noted in Indonesia (Wessing, 1999; Wadley \& Colfer, 2004) and elsewhere (e.g. Bhagwat \& Rutte, 2006; Khan et al., 2008). However, not all sacred areas ensure protection for wildlife. For example, Wadley \& Colfer (2004) documented hunting effort among the Iban community in West Kalimantan, where a number of bird and mammal species were captured regularly in a sacred forest. Hunting in the sacred forest was considered acceptable among the Iban, whereas the felling of trees was strictly regulated in accordance with the belief that illness would befall those who did not obey. Such examples highlight the need for location-specific and species-specific understanding of traditional belief systems in assessing their potential application to conservation efforts.

This need is particularly great in Indonesia, which faces considerable logistical challenges in the conservation of its flora and fauna across $>17,000$ islands (Ministry of Environment Indonesia, 2009). These islands are not only home to a variety of endemic species but may also support the undisturbed, wild habitats associated with sacred forests and guardian spirits. As behaviours associated with the belief in forest spirits may prove critical to the protection of Indonesia's biodiversity, continued investigation of taboos throughout the Indonesian archipelago will aid in the consideration of such traditional values in the conservation of wildlife.

\section{Acknowledgements}

We thank Bogor Agricultural University Primate Research Center, the University of Washington Center for Global Field Study, and the Washington National Primate Research Center (ORIP, NIH Grant No. P51ODo10425) for their support and logistical assistance with this ongoing research project. We thank the University of Washington School of Environmental and Forest Sciences for financial support, the staff of Muara Dua base camp and the Tinjil
Island natural habitat breeding facility for their continued assistance, the members of the University of Washington Predator Ecology Lab and Stanley Asah for their helpful feedback, Iqbal Hariadi and Zahrina Noorputeri for their help with facilitating interviews and processing interview data, and Diane Uyeda and Jeff Smith for their comments on this article. This project received approval from the Indonesian Ministry of Research and Technology, permit number 290/SIP/FRP/SM/VIII/2013, and received an exempt determination from the University of Washington Human Subjects Division (study \#44076).

\section{References}

Auerbach, C.F. \& Silverstein, L.B. (2003) Qualitative Data: An Introduction to Coding and Analysis. NYU Press, New York, USA. Auliy a, M. (2006) Taxonomy, Life History and Conservation of Giant Reptiles in West Kalimantan (Indonesian Borneo). Natur und Tier Verlag, Münster, Germany.

Bennett, D., Gaulke, M., Pianka, E.R., Somaweera, R. \& Sweet, S.S. (2010) Varanus salvator. In IUCN Red List of Threatened Species v. 2013.2. Http://www.iucnredlist.org/details/178214/o [accessed 25 March 2014].

Bhagwat, S.A. \& Rutte, C. (2006) Sacred groves: potential for biodiversity management. Frontiers in Ecology and the Environment, 4, 519-524.

CITES (2014) Convention on International Trade in Endangered Species of Wild Fauna and Flora. Appendices I, II and III. Http:// cites.org/eng/app/appendices.php [accessed 21 August 2014].

Colding, J. \& Folke, C. (1997) The relations among threatened species, their protection, and taboos. Conservation Ecology, 1, 6.

Colding, J. \& Folke, C. (2001) Social taboos: "invisible" systems of local resource management and biological conservation. Ecological Applications, 11, 584-600.

Engler, M. \& Parry-Jones, R. (2007) Opportunity or Threat: The Role of the European Union in Global Wildlife Trade. TRAFFIC Europe, Brussels, Belgium.

Groombridge, B. \& Luxmoore, R. (1991) Pythons in South-East Asia: A Review of Distribution, Status and Trade in Three Selected Species. A report to the CITES Secretariat. Lausanne, Switzerland.

Jenkins, M. \& Broad, S. (1994) International Trade in Reptile Skins: A Review and Analysis of the Main Consumer Markets, 1983-91. TRAFFIC International, Cambridge, UK.

Jones, J.P.G., Andriamarovololona, M.M. \& Hockley, N. (2008) The importance of taboos and social norms to conservation in Madagascar. Conservation Biology, 22, 976-986.

Kasterine, A., Arbeid, R., Caillabet, O. \& Natusch, D. (2012) The Trade in South-East Asian Python Skins. International Trade Centre (ITC), Geneva, Switzerland.

Khan, M.L., Khumbongmayum, A.D. \& Tripathi, R.S. (2008) The sacred groves and their significance in conserving biodiversity: an overview. International Journal of Ecology and Environmental Sciences, 34, 277-291.

Koch, A., Ziegler, T., Böhme, W., Arida, E. \& Auliya, M. (2013) Pressing problems: distribution, threats, and conservation status of the monitor lizards (Varanidae: Varanus spp.) of Southeast Asia and the Indo-Australian archipelago. Herpetological Conservation and Biology, 8, 1-62.

Kyes, R.C. (1993) Survey of the long-tailed macaques introduced onto Tinjil Island, Indonesia. American Journal of Primatology, 31, 77-83. 
Lingard, M., Raharison, N., Rabakonandrianina, E., Rakotoarisoa, J.-A. \& ElmQvist, T. (2003) The role of local taboos in conservation and management of species: the radiated tortoise in southern Madagascar. Conservation \& Society, 1, 223-246.

Luxmoore, R. \& Groombridge, B. (1990) Asian Monitor Lizards: A Review of Distribution, Status, Exploitation and Trade in Four Selected Species. World Conservation Monitoring Centre, Cambridge, UK.

Ministry of Environment Indonesia (2009) Fourth National Report: The Convention on Biological Diversity. Biodiversity Conservation Unit, Ministry of Environment, Jakarta, Indonesia.

Ministry of Tourism and Creative Economy, Republic of Indonesia (2013) Discover Indonesia. Http://www.indonesia.travel/ en/discover-indonesia [accessed 12 September 2014].

Pamungkas, J., Sajuthi, D., Lelana, P.A., Iskandriati, D., Joeniman, B., Kyes, R.C. et al. (1994) Tinjil Island, a natural habitat breeding facility of simian retrovirus-free Macaca fascicularis. American Journal of Primatology, 34, 81-84.

Riley, E.P. (2010) The importance of human-macaque folklore for conservation in Lore Lindu National Park, Sulawesi, Indonesia. Oryx, 44, 235-240.

Shine, R., Ambariyanto, Harlow, P.S. \& Mumpuni (1999) Reticulated pythons in Sumatra: biology, harvesting and sustainability. Biological Conservation, 87, 349-357.

Shine, R., Harlow, P., Ambariyanto, Boeadi, Mumpuni \& KeOGH, J.S. (1998) Monitoring monitors: a biological perspective on the commercial harvesting of Indonesian reptiles. Mertensiella, 9, 61-68.

Thalmann, U., Geissmann, T., Simona, A. \& Mutschler, T. (1993) The indris of Anjanaharibe-Sud, northeastern Madagascar. International Journal of Primatology, 14, 357-381.

Traffic and the IUCN/SSC Wildlife Trade Programme (2004) Taxa identified as possible candidates for inclusion in the review of Significant Trade in Specimens of Appendix-II Species. In Twentieth Meeting of the CITES Animals Committee Johannesburg (South Africa), 29 March-2 April 2004.

UneP (United Nations Environment Programme) (2013a) Python reticulatus. Http://www.speciesplus.net/\#/taxon_concepts/ 5959/legal [accessed March 2014].

UneP (United Nations Environment Programme) (2013b) Varanus salvator. Http://www.speciesplus.net/\#/taxon_concepts/ 5763/legal [accessed March 2014].
UyedA, L.T. (2009) Garbage appeal: relative abundance of water monitor lizards (Varanus salvator) correlates with presence of human food leftovers on Tinjil Island, Indonesia. Biawak, 3, 9-17.

Uyeda, L.T., Iskandar, E., Kyes, R.C. \& Wirsing, A.J. (2012) Proposed research on home ranges and resource use of the water monitor lizard, Varanus salvator. The Forestry Chronicle, 88, 542546.

Uyeda, L.T., Iskandar, E., Purbatrapsila, A., Pamungkas, J., Wirsing, A. \& Kyes, R. (2014) Water monitor lizard (Varanus salvator) satay: a treatment for skin ailments in Muarabinuangeun and Cisiih, Indonesia. Biawak, 8, 35-38.

UyedA, L.T., IskANDAR, E., Wirsing, A. \& Kyes, R. (2013) Nocturnal activity of Varanus salvator on Tinjil Island, Indonesia. Biawak, 7 , 25-30.

WAdLey, R.L. \& Colfer, C.J.P. (2004) Sacred forest, hunting, and conservation in West Kalimantan, Indonesia. Human Ecology, 32, 313-338.

WEssing, R. (1999) The sacred grove: founders and the owners of the forest in West Java, Indonesia. In L'homme et la forêt tropicale (eds S. Bahuchet, D. Bley, H. Pagezy \& N. Vernazza-Licht), pp. 59-74. Travaux de la Société d'Écologie Humaine, Marseille, France.

Wessing, R. (2006) A community of spirits: people, ancestors, and nature spirits in Java. Crossroads: An Interdisciplinary Journal of Southeast Asian Studies, 18, 11-111.

\section{Biographical sketches}

LINDA UYEDA is interested in the study of both wildlife behaviour and human dimensions as an interdisciplinary basis for informing conservation. ENTANG ISK ANDAR has been carrying out wildlife population surveys for over 13 years and studying the human-primate interface in Indonesia for more than 8 years. Azhari PURBATRAPSILA has been working with wildlife and studying herpetofauna and primate conservation for more than 5 years. Jo Ko PAMUNGKAs has been researching primate virology for over 25 years, with a focus on emerging infectious disease. AARON WirSing studies the ecology and conservation of large predators and how humans can modify interactions involving these species. RANDALL KYES has extensive field study experience in Indonesia, focusing on the human-environment interface. 